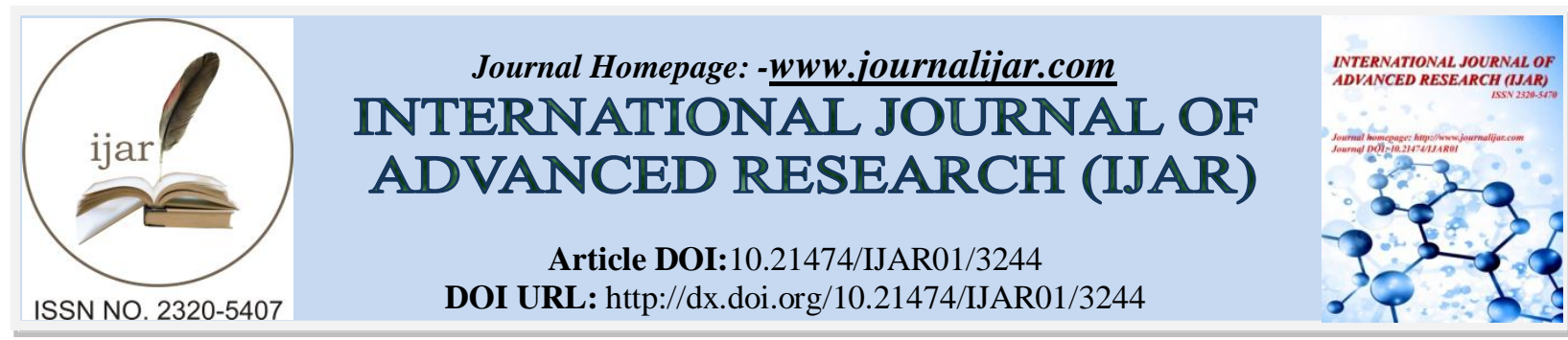

RESEARCH ARTICLE

\title{
ROLE OF NANOTECHNOLOGY IN EPIRUBICIN FOR BREAST CANCER THERAPY IN TAIF CITY
}

Jaamal Khlood, Aljoaid Linah, Alasmary Manal and Basmah Alazwari.

Department of Pharmacy, clinical Pharmacy, Taif University, Saudi Arabia.

\section{Manuscript Info}

Manuscript History

Received: 22 December 2016

Final Accepted: 24 January 2017

Published: February 2017

Key words:-

Nanotechnology, Epirubicin, cancer,

Breast cancer, nanoparticle, multi wall carbon nanotubes.

\begin{abstract}
Background: According to Breast Cancer Screening Programs in 26 Countries, $19.0 \%$ of females have breast cancer. The aim of our study is assessing the role of nanotechnology in breast cancer therapy. Epirubicin drug was selected as an example of the pharmaceutical nanosystem.

Method: A cross sectional study was conducted among 300 women in Taif city and the data were collected using a self-administered questionnaire. The questionnaire determines the knowledge of risk factors and the disease stages (breast cancer). The patients also interviewed to determine the duration, the response and the feeling of any harmful symptoms after using of Epirubicin in the therapy. The answers were scored; frequencies and percentages were used for describing data. Chi-square test and a $\mathrm{P}$ value of $(0.05)$ were used to determine the significant association between the participants' variables.

Results: Most patients respondents were between 21 to above 70 years old. About $28.1 \%$ breast cancer patients discover the disease by the chance, while $46.9 \%$ by self-examination. $43.75 \%$ of breast cancer patients use Epirubicin drug. The effectiveness of therapy takes about 3 -9 months. $15.6 \%$ only have a serious common side effect and $18.7 \%$ have any side effect. Therefore the number of patients who accepted the therapy by Epirubicin was 78.6\%

Conclusion: Participants had poor knowledge about the disease and management. Using Epirubicin had a good attitude in managing time and compliance of the disease. The nanoparticle system presented in Epirubicin drug considers the solving of most common patient incompliance.
\end{abstract}

Copy Right, IJAR, 2017,. All rights reserved.

\section{Introduction:-}

Thebodyismadeupoftrillionsoflivingcells.Normalbodycellsgrow,dividetomakenewcells, anddieinanorderlyway(apopt osis).Duringtheearlyyearsofperson'slife,normalcellsdividefastertoallowthepersontogrow.Afterthepersonbecomesana dult,mostcellsdivideonlytoreplaceworn-outordyingcellsortorepairinjuries ${ }^{(1)}$.

Whenabnormalcellgrowthisoccurwiththepotentialtoinvadeorspreadtootherpartsofthebodythesecellsiscalledacancerou scellsFig.I-

I.It'sbecomeacancercellsbecauseofDNA(Deoxyribonucleicacid)damage. WhenDNAisdamagedthecelleitherrepairsthe 
damageordies.Incancercells, thedamagedDNAisnotrepaired,butthecelldoesn'tdielikeitshould.Instead,thecellgoesonma kingnewcellsthatthebodydoesn'tneed.Thesecellsarecalledcancercells.Inmostcases, thecancercellsformatumor.Overtim e,thetumorscanreplacenormaltissue, crowdit,orpushitaside ${ }^{(2)}$.

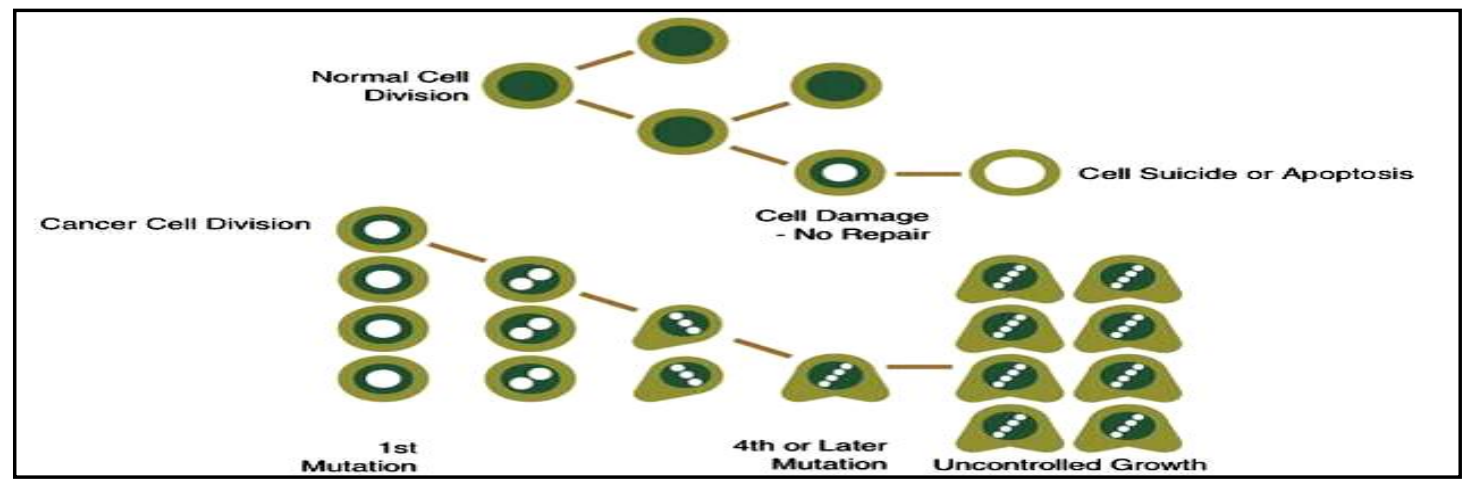

FigI-I:-Normal cell and cancer cell growth

Cancerremainsoneofthemostcommoncausesofmortalityintheworld.AccordingtotheCancerIncidenceReportSaudiArab ia2010andSaudiCancerRegistrycancerisoneoftheleadingcausesofdeathinKSA.About13.706casesofcancerpatientswer einKSA.Thebreastcanceristhemostprevalenceandthemostcommonwhichrankedfirstby27.4\% Fig(I-II) ${ }^{(3)}$.

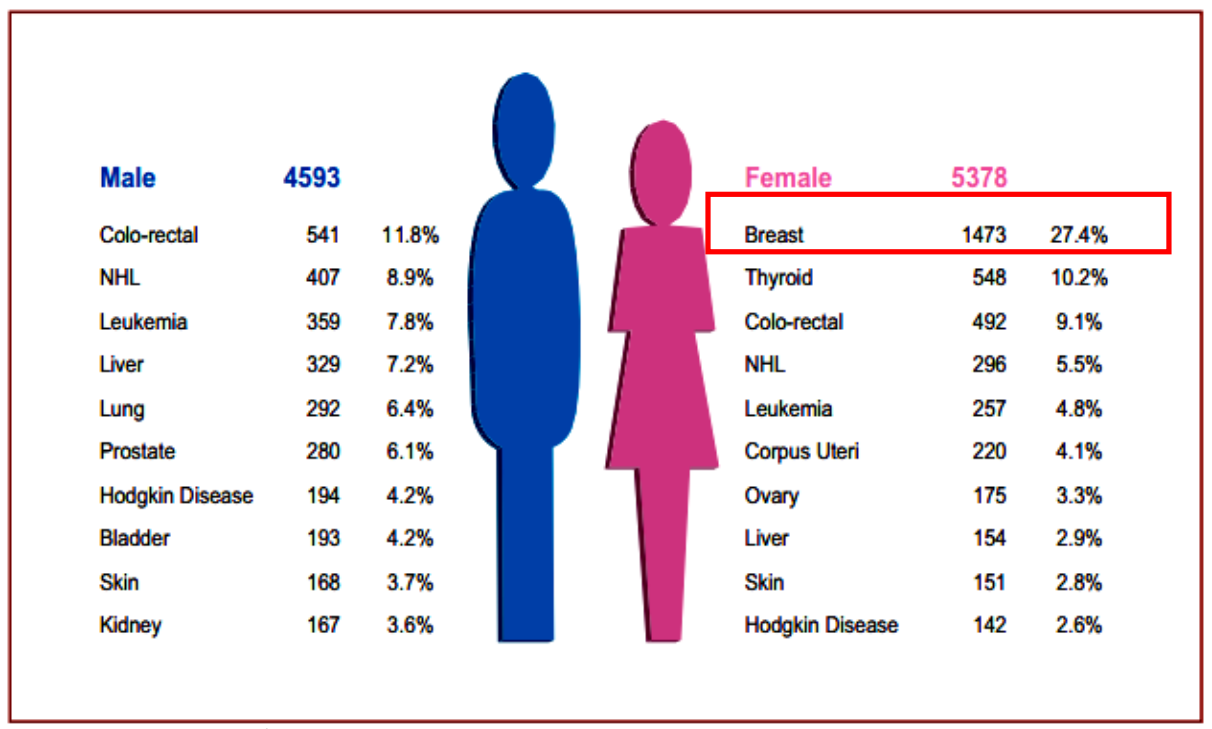

Fig I-II:-Mortality of cancer among KSA population,2010

And according to Breast Cancer Screening Programs in 26 Countries, 2012 : Organization, Policies , and Program Reach when screened 6200 in KSA; $19.0 \%$ of females have breast cancer ${ }^{(4)}$.

Breast cancer begins in the breast tissue that is made up of glands for milk production, called lobules, and the ducts that connect the lobules to the nipple. Theremainder of the breast is made up of fatty, connective, and lymphatic tissues .

Breast cancer may be Ductal carcinoma in situ (DCI) or non-invasive breast cancer which they are abnormal cells. The atypical cells have not spread outside of the ducts into the surrounding breast tissue. Ductal carcinoma in situ is very early cancer that is highly treatable, but if it's left untreated or undetected, it can spread into the surrounding breast tissue (Fig.I-III) ${ }^{(5,6)}$. 

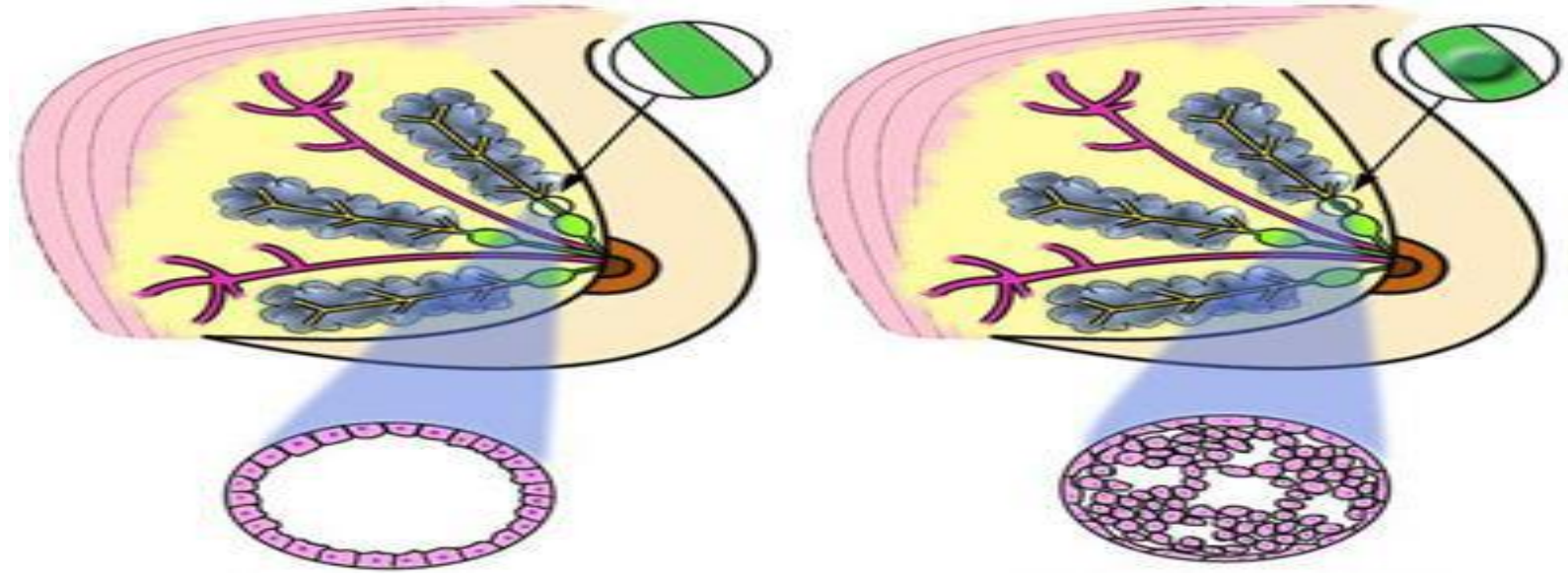

(A)Normalduct(B) ductal carcinoma In Situ (DCIS)

Fig I-III:- Ductal Carcinoma In Situ.

Anothertypeofbreastcancerisinvasiveductcarcinomawhichthecancerouscellsbrokenthroughtheductalorglandularwallsi ntosurroundingbreasttissueorspreadtootherpartsofthebodyFig.IV

It'sconsiderthemostpronouncedtypeandit'sdangerousonitsstage.

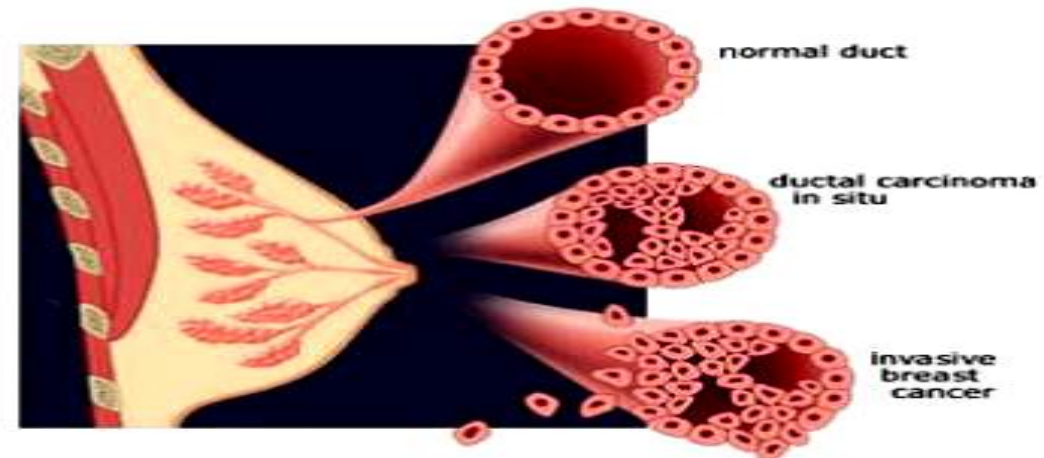

Fig I-IV:-Invasive carcinoma.

EspeciallyTheprognosisofinvasivebreastcancerisstronglyinfluencedbythestageofthedisease.Cancerhavemanystages, $\mathrm{S}$ tageI;Thisisusuallyasmallcancerortumorthathasn'tgrowndeeplyintonearbytissuesandhasn'tspreadtothelymph nodesor otherpartsofthebody.Itisoftencalled early stagecancer,StageIIandIII thesestagesindicatecancerortumorsthatarelargerinsize,havegrownmoredeeplyintonearbytissue, andhavespreadtolymph nodes, butnottootherpartsofthebodyandStageIV

thisstagemeansthatthecancerhasspreadtootherorgan sorpartsofthebody.Itmayalsobecalledadvancedormetastaticcancer. $\operatorname{Fig}(\mathrm{I}-\mathrm{V})^{(7)}$.

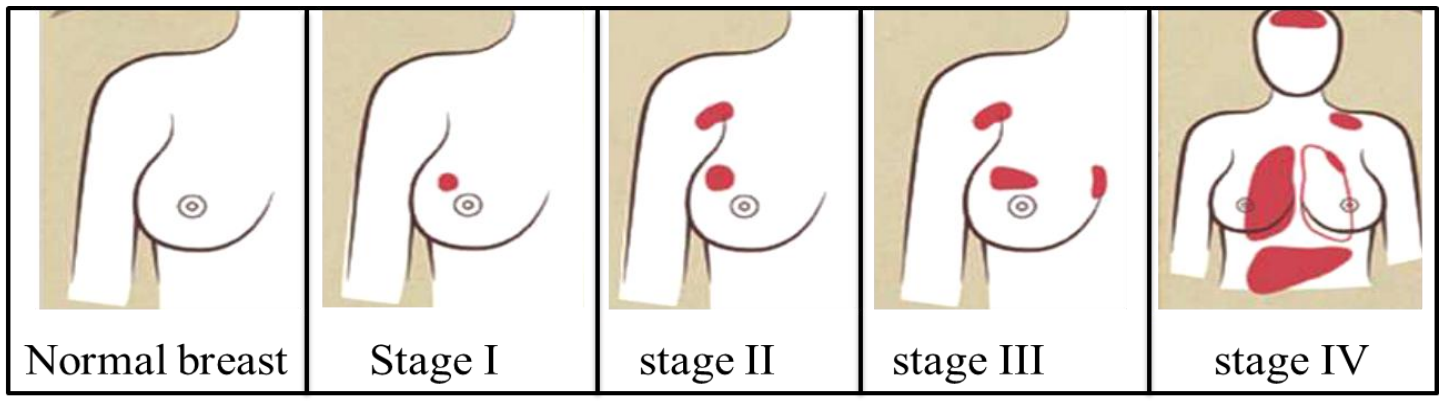


Fig I-V:- stages of breast cancer

There are many factors that help in increasing the probability of the breast cancer disease. There are many studies to determine them , According to American cancer society risk of developing breast cancer increases as getting older. About 1 out of 8 invasive breast cancer are found in women younger than 45, while about 2 of 3 invasive breast cancer are found in women age 55 or older ${ }^{(8)}$.

About $5 \%$ to $10 \%$ of breast cancer cases are thought to be hereditary, meaning that they result directly from gene defects (called mutations) inherited from a parent. Breast cancer risk is higher among women whose close blood relatives have this disease, less than $15 \%$ of women with breast cancer have a family member with this disease.

Thismeansthatmost(over85\%)womenwhogetbreastcancerdonothaveafamilyhistoryofthisdisease.Theprobabilityincrea seasawomanwithcancerinonebreasthasa3 $\quad-\quad$ to 4

foldincreasedriskofdevelopinganewcancerintheotherbreastorinanotherpartof thesamebreast ${ }^{(9)}$.

AccordingtoAmericanInstituteforCancerResearchandWorldCancerResearchFundlifestyleisthemajorcauseofcancerrel atedillness. Thisfindingwasexpressedafterexaminingpeopleacrosstheglobeandlookingathalfamillioncancerrelatedstudi es.TheyfoundthatSixtypercentofcancercanbeattributedto lifestyle choicesofsmoking,poordietandobesity.

Changesinhormonelevelscaninterferewiththisprocessandthatcanleadtocancer,theexposedto toxic chemicalsinourdailylivesfromawiderangeofsourcescanincreasecancerrisk,sunlight,radiationandinfectiousagent(bacter ia,virus)cancausecancer, Whilethehereditaryfactorsaccounta6\% ofcauses ${ }^{(10)}$.

\section{Cancertherapy:-}

Cancertreatmentiscurrentlyamajorfocusofinvestigation whichhavemanytreatmentoptionsthatincludeSurgery, Radiatio ntherapy,ChemotherapyandTargetedtherapy.

Treatmentdecisionsaremadebythepatientandthephysicianafterconsiderationoftheoptimaltreatmentavailableforthestag eandbiologicalcharacteristicsofthecancer, thepatient'sageandpreferences, andtherisksandbenefitsassociatedwitheachtr eatmentprotocol.

Treatmentslike radiation andsurgeryareconsideredlocaltreatments, theyactonly on the infected area such as thebreast,lung, and prostate, However, they targeted the cancerous cells directly.

Because of hat chemotherapyisthedoctorchoiceincaseofspreading cancer .

Chemotherapyisoneofthemostcommonwaysincancertreatment.Chemotherapyisusingspecificchemicalagentsordrugsth ataredestructivetomalignantcellsandtissuesinordertocurepatients.Chemotherapy cannot differentiatebetweennormalcellsandcancercells; whichmeansthechemotherapytargetscellwhethernormalorcancerousc ells. Thelaterleadstoharmthehealthycellswhichhaveahighrateofgrowthandmultiplicationincludecellsofthebonemarrow, hair,GImucosaandskin. Thesesideeffectsmaybecausecardiotoxicity pulmonaryfibrosis,Severityofsideeffectsvariesbetweendrugs ${ }^{(11)}$.

Thereareotherwaysfortreatmentasexercise.Exerciseisaneffectiveinterventionto improve qualityoflife, cardiorespiratoryfitness, physicalfunctioningandfatigueinbreastcancerpatientsandsurvivors.Largertrialsthathaveagreat erfocusonstudyqualityandadverseeffectsandthatexaminethe

benefitsofexerciseareneededforthispatientgroup. Pre-to posttestanalysesrevealedthatwomenwhoexercisedhadsignificantlylessdepression stateandtraitanxietyovertimecomparedtocontrols. Afterthecrossover, thecontrolgroupdemonstratedcomparableimprove mentsinbothdepressiveandstateanxietyscores. Self-

esteemdidnotchangesignificantly.Subjectswhoreceivedexerciserecommendationsfromtheirphysiciansexercisedsignifi cantlymorethansubjectswhoreceivednorecommendation ${ }^{(12)}$.

Researchers

worldwide havebeensearchingforanoptimalcancertreatmentwithoutafflictingsignificantmorbidity.Recentadvancesincancernanote 
chnologyhaveraisedexcitingopportunitiesforspecificdrugdeliverybyanemergingclassofnanotherapeuticsthatmaybetar getedtoneoplasticcellsonly ${ }^{(13)}$.

The

Nano

sized

drugdeliverysystemsallowdepositionofmedicationsinthedesiredareasofthebodyascancercells.Ithelpsinformationoftarg ettherapywhichimprovedthecancertherapy ${ }^{(14)}$.

Several nanoparticle technologies are currently progressed to clinical use. Currently, FDA approved some drug products employing this technology Table I-I.

Table I-I:-FDA approved some drug products employing this technology

\begin{tabular}{|c|c|c|c|}
\hline Agent & Sponsor & Use/ Technology & Approval date \\
\hline Megace ES & ParPhamaceuticals & $\begin{array}{l}\text { Appetitestimulant/Elan'sNanoCrystaltechnof- } \\
\text { ogy }\end{array}$ & July 2004 \\
\hline Abraxane & APP & Broast cancer/Albumin-bound paclitaxel & January 2005 \\
\hline Doxil & Alza Corporation & $\begin{array}{l}\text { OvariancancerandKaposi'ssarcoma/STEALTH } \\
\text { technology }\end{array}$ & February 2005 \\
\hline Emend & Merck \& Co. & $\begin{array}{l}\text { Antiemeticfordhemotherapy/Elan's Nanocrystal } \\
\text { technology }\end{array}$ & March 2003 \\
\hline Tricor & AbbottLaboratories & $\begin{array}{l}\text { Cholesterol-lowering/Elan'sNanoCrystattechnot- } \\
\text { ogy }\end{array}$ & December 2004 \\
\hline Estrasorb & Novavax, Inc. & $\begin{array}{l}\text { Severevasomotorsymptoms/Novavax'smicellar } \\
\text { nanoparticle drug-delivery platform }\end{array}$ & October 2003 \\
\hline Rapamune & Wyeth & $\begin{array}{l}\text { Immunosuppressant/Elan'sNanoCrystaltech- } \\
\text { nology }\end{array}$ & August 2000 \\
\hline Articoat & Smith\&Nephew & $\begin{array}{l}\text { Antimicrobialdressing/Silver-containingSIL- } \\
\text { CRYST Nanocrystals }\end{array}$ & May 2005 \\
\hline SilvaGard & AcryMed, Inc & Antimicrobial(silver)surfacetreatment/Silvakgard & December 2005 \\
\hline Zirconiumoxicle & $\begin{array}{l}\text { AltairNanotechnolo- } \\
\text { gies, Inc. }\end{array}$ & $\begin{array}{l}\text { Dentalapplications/Nano-sizedzirconiumoxide } \\
\text { isstrongandtransparenttolight, butopaqueto } \\
\text { x-rays }\end{array}$ & September 2003 \\
\hline
\end{tabular}

One of these technologies is Carbon nanotubes.Carbon nanotubes are hexagonal networks of carbon atoms, $1 \mathrm{~nm}$ in diameter and 1-100 nm in length, as a layer of graphite rolled up into a cylinder. There are two types of nanotubes: single-walled nanotubes (SWNTs) and multi-walled nanotubes (MWNTs) as represented in Fig VI which differ in the arrangement of their graphenecylinders. These are small macromolecules that are unique for their size, shape, and have remarkable physical properties ${ }^{(15)}$.

Some distinct advantages of carbon nanotubes over other drug delivery and diagnostic systems were their very interesting physicochemical properties such as ordered structure with high aspect ratio, ultra-light weight, high mechanical strength, high electrical conductivity, high thermal conductivity, metallic or semi-metallic behavior and high surface area ${ }^{(16)}$.

Epirubicin is a drug depending on MWNTs, The Combination chemotherapy and Nanoparticle drug delivery are two areas that have shown significant promise in cancer treatment. Combined therapy of two or more drugs promotes synergism among the different drugs against cancer cells and suppresses drug resistance through distinct mechanisms of action. Nanoparticle drug delivery, on the other hand, enhances therapeutic effectiveness and reduces side effects of the drug payloads by improving their pharmacokinetics.

Multi-wall nanotubes (MWNTs) are coaxial assembly of SWNTs have diameter close to $5 \mathrm{~nm}$ to $50 \mathrm{~nm}$, The interlayer distance in MWNT is close to the distance between graphenelayers in graphite ${ }^{(17)} \mathrm{Fig}(\mathrm{I}-\mathrm{VI})$.

Epirubicin is an Anthracycline drug used for chemotherapy. It can be used in combination with other medications to treat breast cancer, Anthracyclines are considered to be among the most active available agents to treat breast cancer and have become core components of adjuvant regimens. Epirubicin-taxanes combinations are active in treating breast cancer and do not appear to be associated with any pharmacokinetic interactions.

According to table I-II Epirubicin Hydrochloride use MWNTs (Fig. I-VI-B) technology which are layers of graphite with an enormous surface area and an excellent electronic and thermal conductivity ${ }^{(18)}$. 
Table I-II:- Carbon Nanotube as DDS

\begin{tabular}{lll}
\hline Type of nanotubes & Drug & Method of immobilization \\
\hline MWCNTs & Cisplatin & Encapsulation via capillary forces \\
f-CNTs & Amphotericin B & Conjugated to carbon nanotubes \\
SWCNTs & Gemcitabine & Encapsulation \\
MWNTs & Epirubicin hydrochloride & Adsorption \\
MWCNTs@poly(ethylene & Doxorubicin & Adsorption \\
glycol-b-propylene sulfide) & & \\
f-CNTs & Sulfamethoxazole & Adsorption \\
SWNTs-PL-PEG-NH & Covalent amide linkages \\
SWNTs & Pt(IV) prodrug-FA & Attachment to carbon nanotubes via amide \\
& Cisplatin - EGF & linkages \\
MWCNTs & Dexamethasone & Encapsulation \\
\hline
\end{tabular}

MWCNTs multi walled carbon nanotubes; f-CNTs functionalized carbon nanotubes; SWNTs-PL-PEG-NH2 aminefunctionalized single-walled carbon nanotubes.

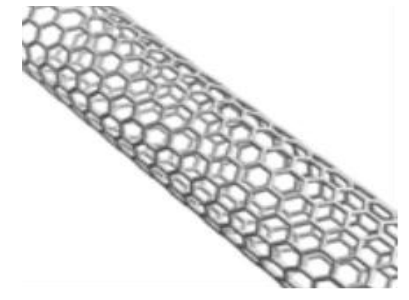

(a)Singlewalled(SWNTs)

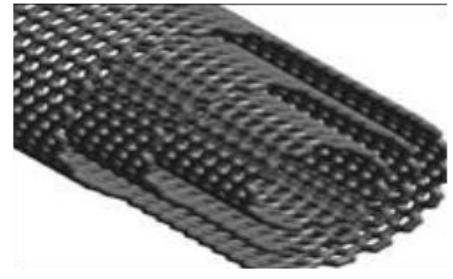

(b)Multiwalled(MWNTs)

\section{Fig I-VI. Carbon nanotubes}

Epirubicin acts by intercalating DNA strands. Intercalation results in complex formation which inhibits DNA and RNA synthesis. It also triggers DNA cleavage by topoisomerase II, resulting in cell death. Binding to cell membranes and plasma proteins may be involved in the compound's cytotoxic effects. Epirubicin also generates free radicals that cause cell and DNA damage ${ }^{(19)}$.

Epirubicin is also involved in oxidation/reduction reactions by generating cytotoxic free radicals. The antiproliferative and cytotoxic activity of Epirubicin is thought to result from these or other possible mechanisms. All these mechanisms improve its anticancer activity ${ }^{(20)}$.

Epirubicin Hydrochloride for Injection is an Anthracycline cytotoxic agent, intended for intravenous administration. Epirubicin Hydrochloride for Injection is supplied as a sterile, orange-red, lyophilized powder in single-dose vials containing $50 \mathrm{mg}$ or $200 \mathrm{mg}$ of Epirubicin hydrochloride. Each $50 \mathrm{mg}$ and $200 \mathrm{mg}$ vial contains $250 \mathrm{mg}$ and 1000 $\mathrm{mg}$ inactive ingredient, lactose, respectively ${ }^{(21)}$.

Following intravenous administration, Epirubicin is rapidly and widely distributed into the tissues. Binding of Epirubicin to plasma proteins, predominantly albumin, is about $77 \%$ and is not affected by drug concentration. Epirubicin also appears to concentrate in red blood cells; whole blood concentrations are approximately twice those of plasma ${ }^{(22)}$. 
Epirubicin is extensively and rapidly metabolized by the liver and is also metabolized by other organs and cells, including red blood cells. Epirubicin and its major metabolites are eliminated through biliary excretion and, to a lesser extent, by urinary excretion. Common side effects; Nausea, vomiting, diarrhea, abdominal pain, flushing, or skin/nail color changes may occur, Temporary hair loss. Serious side effects; bone marrow suppression; including leucopenia, thrombocytopenia and anemia, Myocardial toxicity; including heart failure ${ }^{(23)}$.

\section{Management:-}

$>$ Measurements of CBC, ECG, Liver function test, serum creatinine, and electrolytes

$>$ premedication with an antiemetic may be useful because Epirubicin is emetogenic .

$>$ Infusion site must be monitored closely to prevent extravasations; sever local tissue necrosis will result if extravasations occur .

$>$ Monitor for acute nausea, vomiting, anemia, infection, bleeding, and cardiotoxicity ${ }^{(24)}$.

The aim of our study is to determine the prevalence of breast cancer in Taif city Also we study the risk factors which increase the prevalence of the disease. Most studies were done on Europe women. We do our study on Saudi women as all risk factors were variable. We also try to assess the role of nanotechnology in breast cancer therapy. Epirubicin drug was selected as an example of the pharmaceutical nanosystem which is very effective in breast cancer therapy .

\section{Methodology and Design:-}

PurposeandResearchobjectives:-

$>$ TheprimarypurposeistodeterminetheprevalenceofbreastcancerinTaifcity.

$>$ ThesecondarypurposeistodeterminetheroleofNanotechnologyinbreastcancertherapy.

$>$ Thethirdis to determine theEfficacyofEpirubicindruginbreastcancertherapy.

\section{Setting:-}

Theoncologyandpharmacydepartmentsof the hospital.

\section{Studydesign:-}

Acrosssectionalstudyallocatedforbreastcancerfemalepatient,todeterminetheroleofnanotechnologyinbreastcancerthera pyduringtheperiodfromSeptember2014till December 2015

\section{SettingsandDuration:-}

Thestudywasconductedindepartmentsofoncologyandpharmacyof the hospital.Thestudywascarriedoutforover a year (FromSeptember2014till December 2015).

\section{Samplevolumeandselection:-}

Asamplecomposedof300womeninTaif city, ageswasbetween21toabove70yearsold

\section{Tool of data collection:-}

A structured questionnaire was designed for data collection by the researchers based up on review of literature. It includes three parts, The first part: the socio-demographic data, such as: age; residency, occupation, age at menarche, marital status; age of bearing the first baby and the age of married as the later increases the probability of breast cancer.

The second part; the way of discovering the disease and the risk factors increase the prevalence of breast cancer

The third part; type of treatment that patient has, like; radiation therapy, chemotherapy or surgery. Also the effect of using Epirubicin in her therapy or not was studied.

The role of nanotechnology in treatment appears by using Epirubicin as a model drug. We study the effectiveness of using this drug in enhancing the therapy, and reducing or inhibition any side effects from the therapy .

\section{Method:-}

we conducted cross sectional study, the data was collected from face to face interview and the patient files presented in oncology department or computerized in patients files of the hospital. Data also collected by asking nurses, 
doctors and pharmacists. All are answered the questionnaire and their answers were collected. All data has been statistically analysis to specify a recommended answer.

\section{Ethical considerations:-}

Official permission on this study was obtained from the previous sponsors. Hospital, doctors, nurse and pharmacist were informed about the nature of the study. Oral consent obtained from doctors nurse and pharmacist who agreed to participate in the study. We accessed patients' files from the pharmacy department after an official permission.

\section{Inclusion criteria:-}

$>$ Adult female no matter the nationality

$>$ Female patients with breast cancer

$>$ Age between 21 years and above 70 years.

$>$ No matter any other disease condition

$>$ Patient using Epirubicin in there therapy

$>$ New or recurrence case

$>$ Benign or malignant tumor .

\section{Exclusion criteria:-}

$>$ Female patient under 21 years old

$>$ Non-breast cancer patients

$>$ Male cancer patient

$>$ Pregnant and nursing women

$>$ Patient who are not using Epirubicin in there therapy .

\section{Statistical Analysis:-}

All data in this study are expressed in the form of mean. Frequencies and percentages were used for describing data, chi-square test was used with a significance level of $P<0.05$. Statistical analysis was used to determine the prevalence of breast cancer in Taif city, and role of nanoparticles in Epirubicin in breast cancer therapy by measuring the efficacy and harms of the drug.

\section{Research end point:-}

The primary end point:-was the effectiveness of the drug in the therapy

Secondary end point:-

1. Reducing the most common side effect

2. Frequencies of the patient hospital income

\section{Results andDiscussions:-}

Thisstudyaimedtoassesstheprevalenceofbreastcancerin TaifcityandtodeterminetheroleofnanotechnologyinEpirubicindruginbreastcancertherapy.Acrosssectionalstudywas conducted among 300 women in Taif city. Data were collected using aself-administered questionnaire which included questions about the socio-demographic data, knowledge ofrisk factors that may cause the breast cancer, way of discovering the disease, kind of therapythat thepatientreceived, useofEpirubicindrugintherapy,durationandresponseoftherapyandif the patient feels any harmsymptoms.

\section{The prevalence of the breast cancer in Taif city:-}

Threehundredparticipantswereinterviewedinthisstudy.Maleswere excludedfromthatsurvey.Thebreastcancerwasmore predominantinfemalepatients. Alsothebreastcancerpatients only are included in the survey. Only 32 women have breast cancer in the period ofthe studySeptember2014tillDecember 2015 were taketheirmedicationinthe hospital(FromSeptember2014 and followed up the patient condition until December 2015 ). The percent of the breast cancer women is more than $10 \%$ in 15 months from September2014tillDecember 2015. Thisresult wasapproximatelymatchedwiththeresultsof cancercentersurveywhichfoundthatapproximately 12.3 percent of women will be diagnosed with breast cancer at based on2009- 2011 data. For this reason, the World Health Organization considered breast cancer, oneof the most important causes of death in women ${ }^{(25)}$. 


\section{Demographics:-}

Sample distribution by agevariable:-

Therewasavariation intheinterviewedagegroup.Thedatawereillustrated intable(1-A)and Fig. (1-A). The highest percentage of women with breast cancer are in the age group(4150),theyreachedupto31.3\% whilethelowestpercentagewasattheagegroup $(>70 \%)$, whichreached $(9.4 \%)$. Thatindicatesth atwomenbetweenage41-

50yearsoldmoresusceptibletothediseasefromothers.Statisticalanalysisfoundthattherewasnosignificantincreaseintheris kobservedintheadultageandyoungeragewomen. These resultswereagree with the previously reported by Ahmedin Jemal, 2007 et al and Shahbazi R,2015 etal ${ }^{(26,27)}$

Table 1-A:- Sample distribution by agevariable

\begin{tabular}{|l|l|lr|}
\hline Age & number of patients & Percent $\%$ & \\
\hline $21-30$ & 4 & $12.5 \%$ & \\
\hline $31-40$ & 5 & $15.6 \%$ & $\mathbf{1 -}$ \\
\hline $41-50$ & 10 & $31.3 \%$ & $\mathbf{2}-$ \\
\hline $51-60$ & 5 & $15.6 \%$ & $\mathbf{3}-$ \\
\hline $61-70$ & 5 & $15.6 \%$ & $\mathbf{4}-$ \\
\hline$>70$ years & 3 & $9.4 \%$ & $\mathbf{5 -}$ \\
\hline total & 32 & $100 \%$ &
\end{tabular}

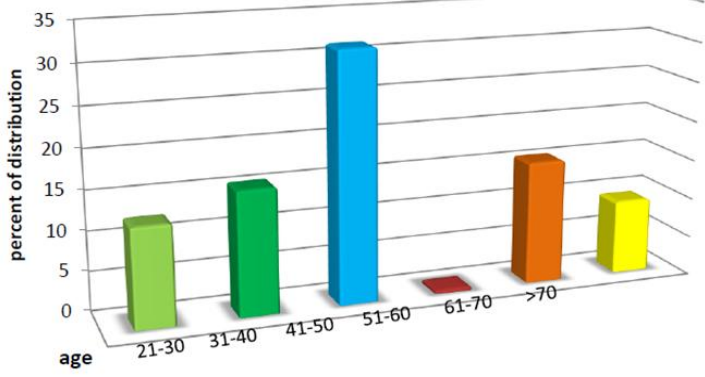

Fig.(1-A )Sample distribution by age variable

Distribution of the sample by materialstatus:-

Table(2-A)andFig.(2-A)showthatthemostoftherespondentsweremarriedwomen, amounting to $(68.8 \%)$. From the results we suggesting that married women moresusceptible to breast cancer than single one. Croft L, 2014 et also found that, those who are marriedhave higher optimism scores than their unmarried one ${ }^{(28)}$.

Table 2-A:-Distribution of the sample by materialstatus

\begin{tabular}{|l|l|l|}
\hline $\begin{array}{l}\text { Marital } \\
\text { Status }\end{array}$ & Number & Percent \% \\
\hline married & 22 & $68.8 \%$ \\
\hline single & 5 & $15.6 \%$ \\
\hline Absolute & 1 & $3.1 \%$ \\
\hline Widow & 4 & $12.5 \%$ \\
\hline total & 32 & $100 \%$ \\
\hline
\end{tabular}

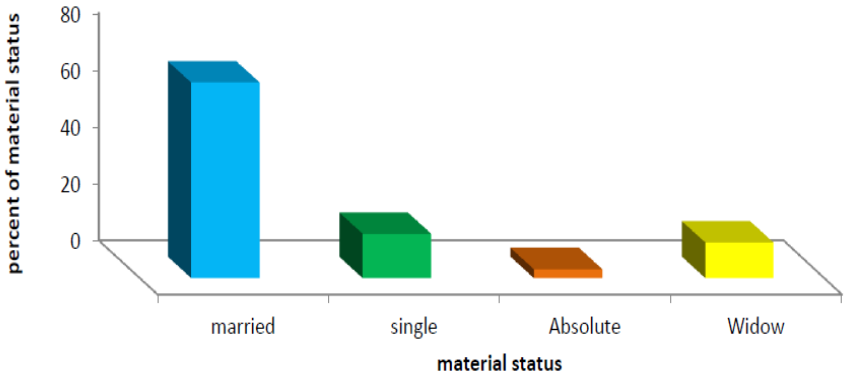

Fig. (2-A) distribution of the sample by material status

Distribution of sample by variableprofession

Supremepercentageofwomenwithbreastcancerinthesample; $43.7 \%$ washousewives. The lowest percentage is students, reaching to $18.6 \%$, as shown in table( 3-A) and figure (3-A) Thelackofmovementislikelytobeanimportantfactorinincreasingofbreast cancer. Women have to go outdoors at least an hour a day because walking helps to renewthe body'scells ${ }^{(29)}$. 
Table 3-A:- sample distribution by variableprofession

\begin{tabular}{|l|l|l|}
\hline Occupation & Numbe & Percent \% \\
\hline student & 6 & $18.7 \%$ \\
\hline employee & 12 & $37.5 \%$ \\
\hline Housewife & 14 & $43.75 \%$ \\
\hline total & 32 & $100 \%$ \\
\hline
\end{tabular}

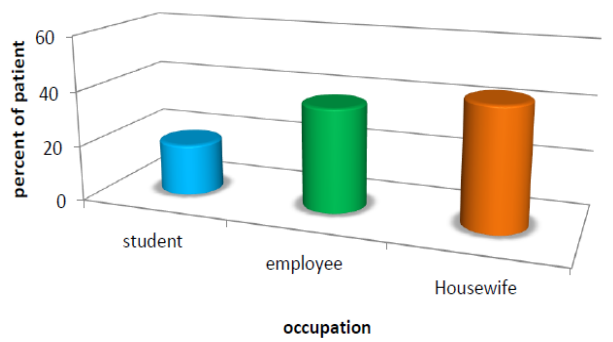

Fig. (3-A) sample distribution by variable profession

\section{Sample distribution by number ofpregnancies}

The results were shown in table (4-A) represent the effect of pregnancy on the prevalenceof thebreastcancer.The highestpercentageofwomenwithbreastcancer inthestudysample waswith 1 to5 timesofpregnancyandbreastfeedingregularity(37.5\%).Themotheraftergivingbirthneedtotwoyearstorecoverherbodyfro mtheeffectsofpregnancyandalsoincrease the number of pregnancies reduce the incidence of breast cancer because in thiscase hormoneswouldbeataconstantlevelinthenormalactivity ${ }^{(30)}$.Exceptgoverningalwaysask for reducing the reproductiverate.

Table 4-A:- sample distribution by number ofpregnancies

\begin{tabular}{|l|l|l|}
\hline No. of pregnanttimes & No. ofpatients & Percentof \\
\hline non & 7 & 21.9 \\
\hline 1 to5 & 12 & 37.5 \\
\hline 6 to 10 & 8 & 25 \\
\hline 10 to15 & 5 & 15.6 \\
\hline total & 32 & 100 \\
\hline
\end{tabular}

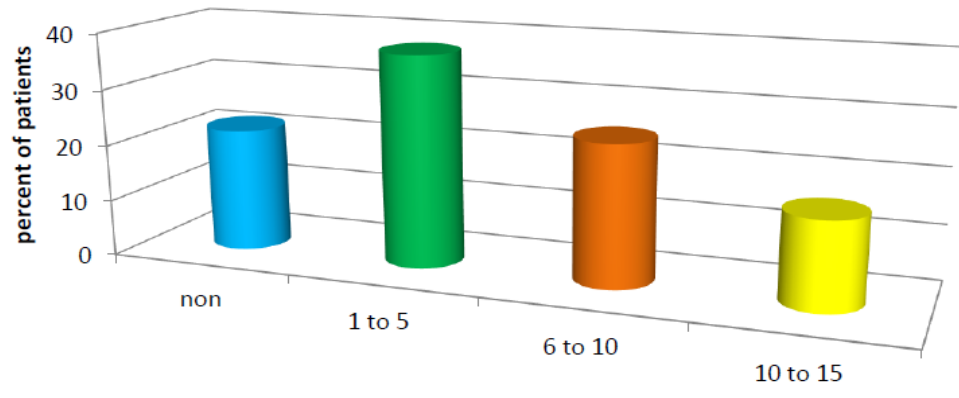

pregnency times

Fig. (4-A) sample distribution by number of pregnancies 
Age of married and bearing the first baby:-

Theolderageofmarriageandbearingthefirsthaveagreateffectivenessincausingthe breast cancer. Both events at age 30 or older increase the risk up to 7.0 times relative towhen botheventsoccurredyoungerthanage20. Whereasthecorrespondingriskwas1.4times whenagebetween2030years. Theseresultswereagreementwiththepreviouslyreported result ${ }^{(31)}$.

Table 5-A:- Age of married and bearing the firstbaby.

\begin{tabular}{|l|l|l|l|l|}
\hline \multirow{2}{*}{} & \multicolumn{2}{|l|}{ Age ofmarried } & \multicolumn{2}{l|}{ Age of bearing the first baby: } \\
\cline { 2 - 5 } & No. & $\%$ & No. & $\%$ \\
\hline$<$ 20years & 3 & 9.87 & 4 & 11.53 \\
\hline 20-30 years & 8 & 23.29 & 3 & 9.96 \\
\hline$>$ 30years & 21 & 66.84 & 25 & 78.51 \\
\hline
\end{tabular}

Age of married \%

Age of bearing the first baby: \%

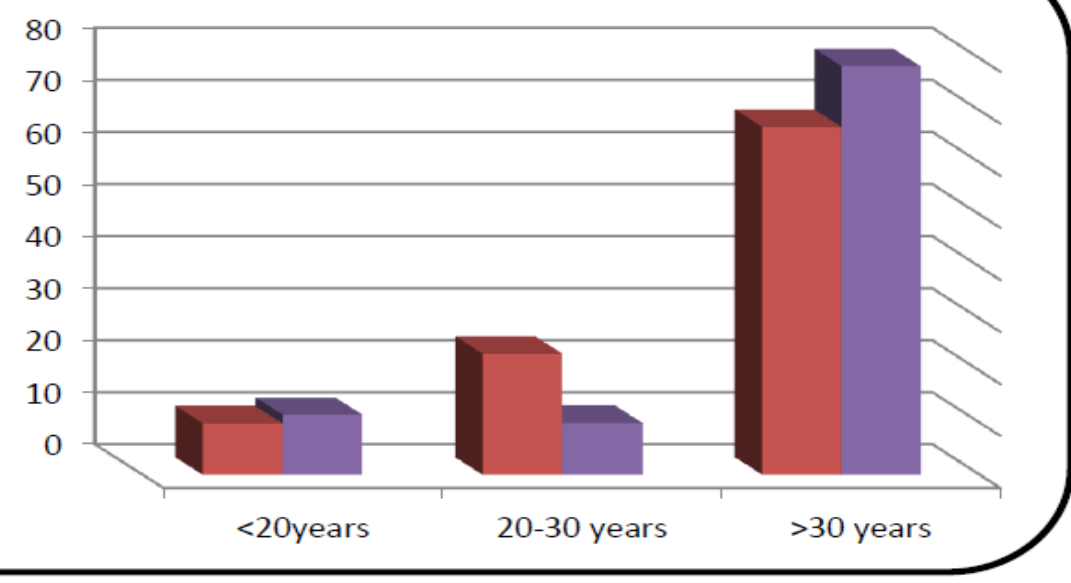

Fig. (5-A) Age of married and bearing the first baby

\section{B-The way of discovering the disease and the risk factors increasetheprevalence of breastcancer}

\section{Sample distribution by riskfactors}

Table 1-B:-risk factors in breast cancer from the perspective ofpatients

\begin{tabular}{|c|c|c|}
\hline cause & percent & number ofpatient \\
\hline Age & 40.6 & 13 \\
\hline hereditary & 15.6 & 6 \\
\hline Cigarettesmoking & 3.13 & 3 \\
\hline Changes in hormonelevels & 9.38 & 3 \\
\hline Toxicchemicals & 9.38 & 2 \\
\hline radiation & 6.25 & 4 \\
\hline diet/obesity & 12.5 & 32 \\
\hline Total & $100 \%$ & \\
\hline
\end{tabular}




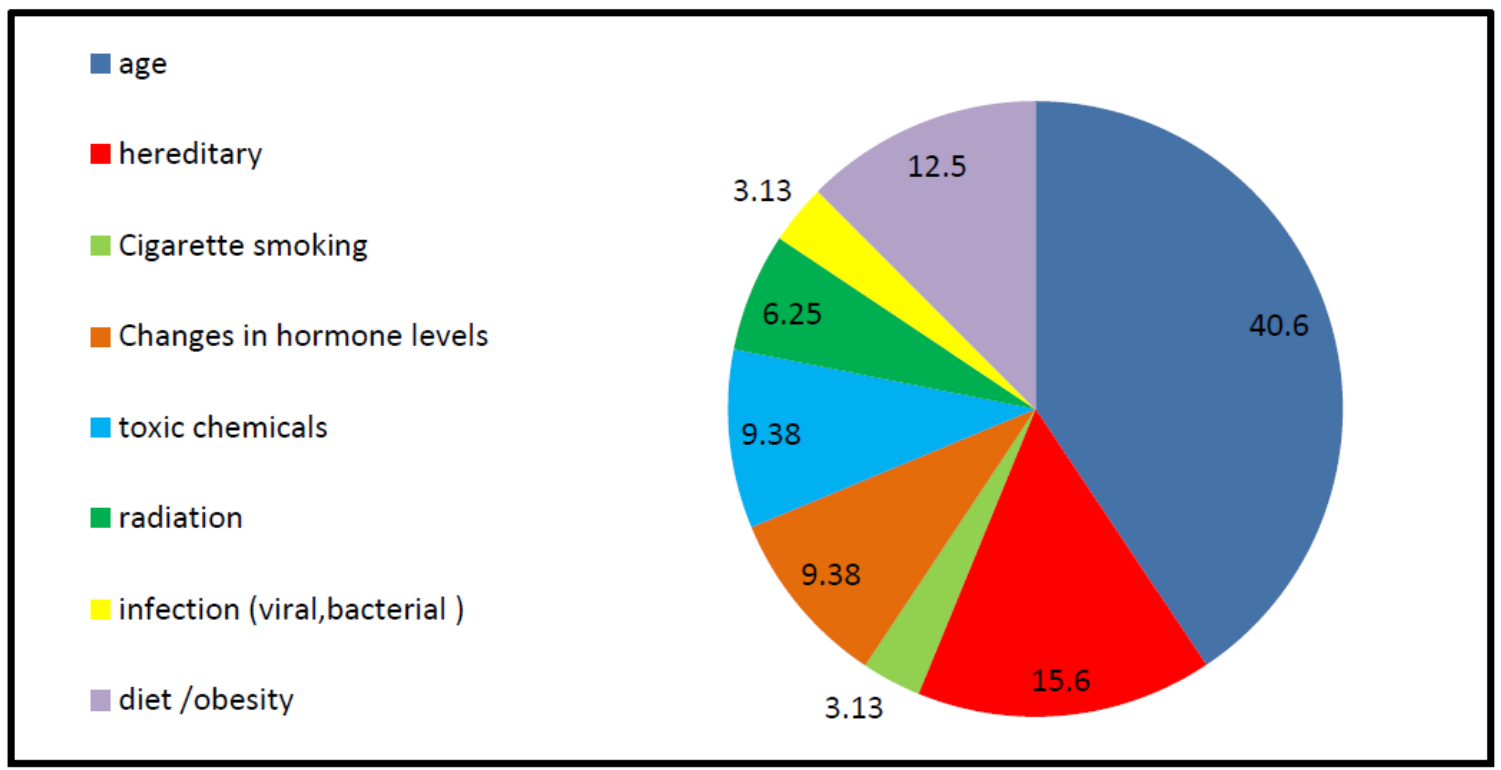

Fig. ( 1-B) sample distribution by risk factors .

Wefoundinourquestionnairetable(1-B);theriskofbreastcancerincreasebyageing $(40.6 \%)$, the hereditary factors develop risk by $(15.6 \%)$. It was reported that a familyhistory of breast cancer had little effect on the risk in women with nonproliferativelesions.

However, the risk in women with atypical and a family history of breast cancer waseleven times that in women who had non-proliferative lesions without a family history ${ }^{\left({ }^{32)}\right.}$.

The change in hormone levels and the toxic chemicals increase risk by $9.38 \%$ only.Statistical analysis shows no significant difference between the results of both risks $(\mathrm{p}>0.05)$.While thechanginginlifestyleconsideredasecondcauseofdisease $(12.5 \% \%)$. Theincreaseofthe

bodyfatnessincreasetheriskofbreastcancer.ThereTheWorldCancerResearchfoundthatevidence increase the relative risk lpostmenopausal breast cancer ${ }^{(33)}$.

because adipose-associatedwith obesityincreasestheconversionof androgentoestrogen,mammaryadiposetissueisthoughttobe animportantsourceoflocalestrogenproduction. Estrogen is a potent mutagen for mammary cells, has long been implicated inthe development of mammary tumors ${ }^{(34)}$. statistical analysis shows a clear significant difference $(\mathrm{p}>0.05)$

\section{1- personal history of breastcancer}

Table 2-B:- Recurrence of breastcancer.

\begin{tabular}{|l|l|l|}
\hline Recurrence & percent & Patientno \\
\hline Yes & 40.6 & 13 \\
\hline No & 59.4 & 19 \\
\hline Total & 100 & 32 \\
\hline
\end{tabular}

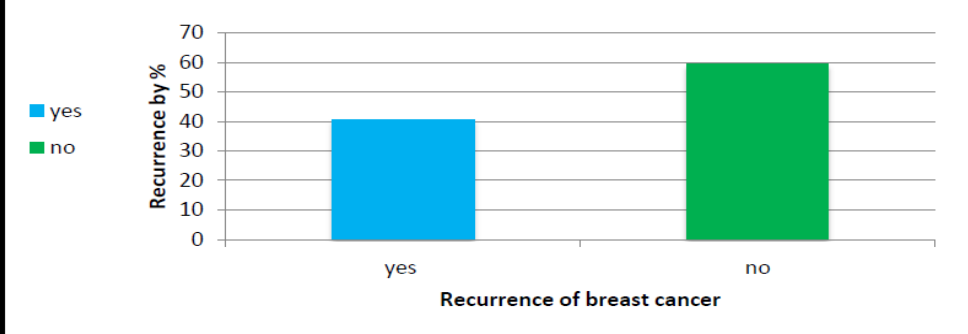

Fig · (2-B) Recurrence of breast cancer

Table (2-B) and figure (2-B) shows that the patient with a new cases of breast cancer is59.4

$\%$; That means the lack of awareness of the breast cancer or increase the probability ofthe disease.Theincrementoftheriskfactormaybe oneofthemaincauses.TheIncreaseawareness of breast cancer risks and detection is necessary ${ }^{(35)}$. 
Time of Menstruation:-

Theearlyage ofmenstruationwasoneofthemaincausesofthebreastcancerdisease.Asshown in table 4 patient who have menstruation before age 12 have a higher risk to getbreast cancer ${ }^{\text {(36) }}$

Table 3-B:- Menstruation time .

\begin{tabular}{|l|l|l|}
\hline Menstruation & Percent \% & PatientNo. \\
\hline before age 12 & $56.25 \%$ & 18 \\
\hline after age12 & $43.75 \%$ & 14 \\
\hline total & $100 \%$ & 32 \\
\hline \multicolumn{2}{|l}{} \\
\hline
\end{tabular}

\section{Menopausetime:-}

Asshownintable(4-B)patientwhohavemenopauseafterage50haveahigherrisktogetbreast cancer. By asking those women most of them take a hormonal replacementtherapy.Importantly, breastcancerriskselevations appeartobehigheramongwomenwhoinitiatetreatmentatthemenopause,comparedtowomendonothavea

menopausaltreatment ${ }^{(37)}$.Menopausalhormonewasacombinationofreproductivehormones; estrogenandprogestinhorm ones.Reproductivehormonesarethoughttoinfluencebreastcancerriskbyincreasingcellproliferation,therebyincreasingth elikelihoodofDNAdamage, aswellaspromotionof cancergrowth. Womenshouldconsidertheincreasedriskofbreastcancerassociatedwiththeuseofestrogenandprogestinwhe nevaluatingtreatmentoptionsformenopausalsymptoms.

Table 4-B:-Menopausetime

\begin{tabular}{|l|l|l|}
\hline Menopausetime & Percent \% & PatientNo. \\
\hline before age 50 & $40.6 \%$ & 13 \\
\hline after age50 & $59.4 \%$ & 19 \\
\hline total & $100 \%$ & 32 \\
\hline
\end{tabular}

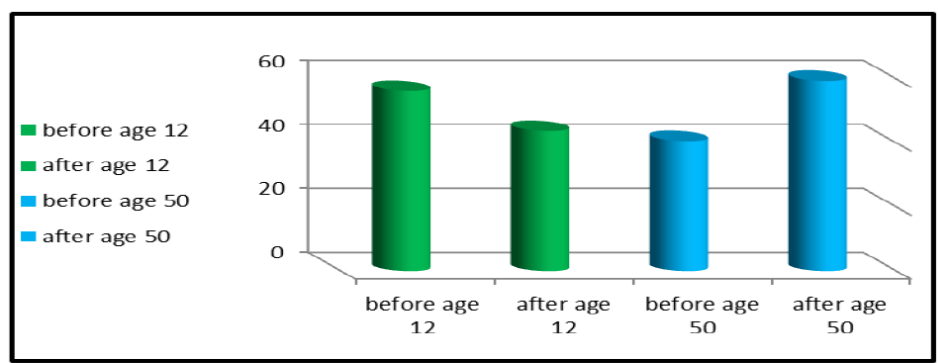

fig. (4-B) Menstruation/Menopause

\section{Discovery of Thedisease:-}

Table (5-B) shows that most common way of discovering the disease. The highestpercentage ofpatientdiscoversthediseasebyself-examinationtests(46.9\%).Thisindicatesincreasingthepatients'awareness which asagreatimportanceinthebreastcancerscreening.Italsoincreases the healing rate ${ }^{(38)}$.

Table (5-B) discovery of thedisease

\begin{tabular}{|l|l|l|}
\hline discover thedisease & number of & percent \% \\
\hline Chance & 9 & 28.1 \\
\hline self-examination & 15 & 46.9 \\
\hline Anotherreason & 8 & 25 \\
\hline total & 32 & $100 \%$ \\
\hline
\end{tabular}

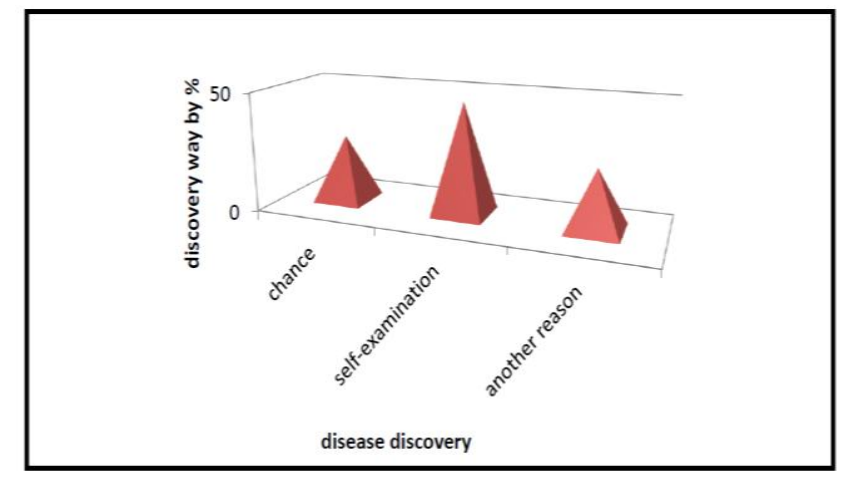

Fig . 5-B discovery the disease 
The role of nanotechnology in the treatments:Sample distribution by kind of therapy.

Table 1-C:-Sample distribution by kind oftherapy

\begin{tabular}{|l|l|l|}
\hline kind oftherapy & Percent\% & PatientNo. \\
\hline chemotherapy & $31.25 \%$ & 10 \\
\hline Targetedtherapy & $50 \%$ & 16 \\
\hline Radiationtherapy & $9.38 \%$ & 3 \\
\hline surgery & $9.3 \%$ & 3 \\
\hline Total & 100 & 32 \\
\hline
\end{tabular}

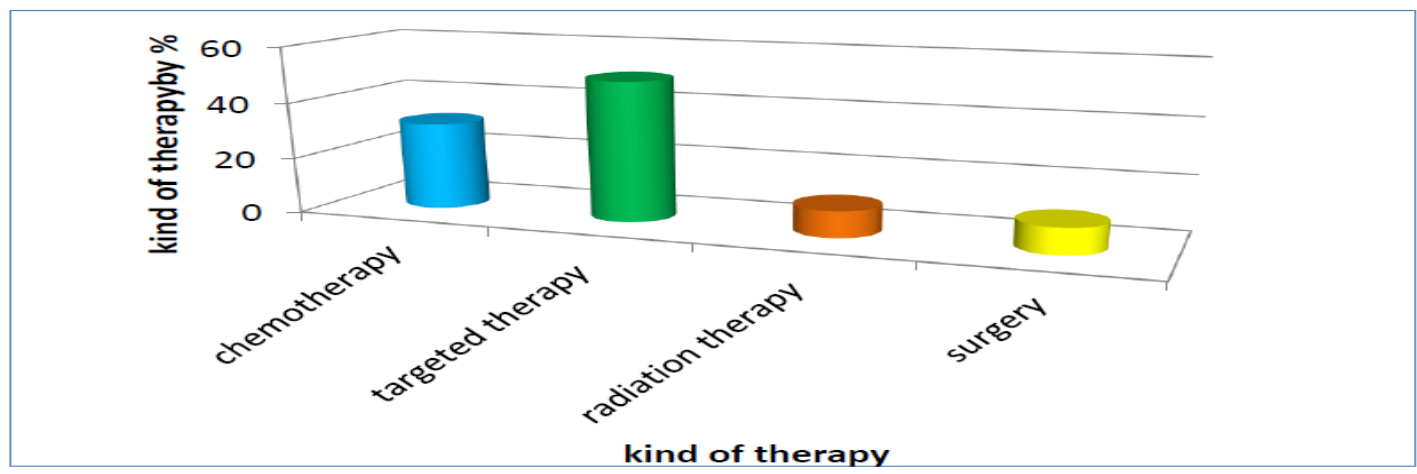

FIg. (1-C) kind of therapy

Fifty percent of patient have a targeted therapy which indicates the importance roleofnanotechnologyinbreastcancertherapytable(1-C).Asmalignancyhasbecomeaserious threattohumanhealth,andmorbidityandmortalityrateshavebeenrisinginrecentyears. Recent studies challenge and interesting is to develop effective therapy for cancer.

SampledistributionoftheusageofEpirubicinanditsInfluenceintherapy.AlthoughthepercentageofpatientusingEpiru bicinintheirtherapy(43.75\%)islessthan who does not use it $(56.25 \%)$ as shown in table (2-C) Table (3-C) but patients whoinfluence agoodeffectivenessfromEpirubicinHClis78.6\%.thepatientswhohaveinappropriate therapy with Epirubicin $\mathrm{HCl}$ are only $21.4 \%$.

Table 2-C:-Sample distribution by use of Epirubicin.

\begin{tabular}{|l|l|l|}
\hline UseEpirubicin & PatientNo. & Percent \% \\
\hline Yes & 14 & 43.75 \\
\hline no & 18 & 56.25 \\
\hline Total & 32 & 100 \\
\hline
\end{tabular}

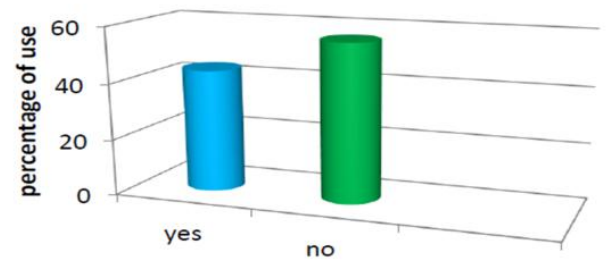

Use of Epirubicin 


\begin{tabular}{|l|l|l|}
\hline $\begin{array}{l}\text { Influence } \\
\text { ofEpirubicin }\end{array}$ & PatientNo. & $\begin{array}{l}\text { percentage } \\
\text { ofeffect }\end{array}$ \\
\hline effective & 11 & $78.6 \%$ \\
\hline Inappropriate & 3 & $21.4 \%$ \\
\hline total & 14 & $100 \%$ \\
\hline
\end{tabular}

Table 3-C:-influence of Epirubicin

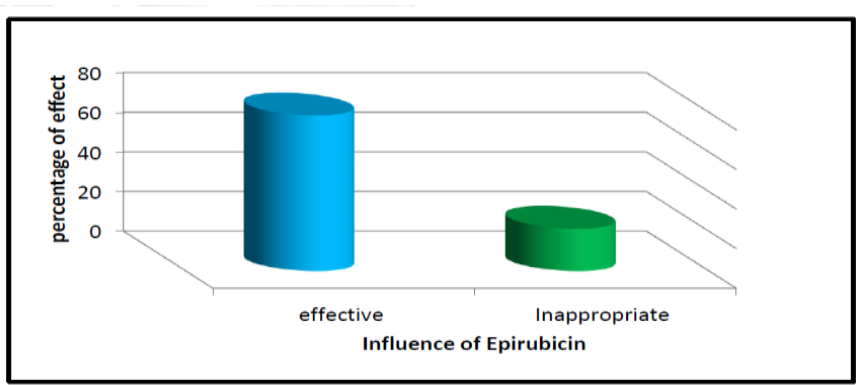

Fig. (3-C) influence of Epirubicin

The duration of using Epirubicin to give an effective therapy inpatients:-

The influence and effectiveness of the medication starts within 3 months of starting treatment, some patients need only to 3 months to show the therapeutic effect ofthe medication they are $18.2 \%$ but the most patients shows the therapeutic effect of the drug in 9 months $54.5 \%$ as table (4-C) shows. The results were agreement with the previously

reportedbyBaldiniE.2002,etalwhofoundthatusingEpirubicininbreastcancertherapy especiallyincombination withcyclophosphamidereducesthedurationoftherapyupto6 months ${ }^{(41)}$.

Table 4-C:-Time that Epirubicin takes to give effect of in patients.

\begin{tabular}{|l|l|l|}
\hline Effective of therapyin/month & Number ofpatients & Percent $\%$ \\
\hline 4 months & 2 & $18.2 \%$ \\
\hline 9 month & 3 & $27.3 \%$ \\
\hline 14 months & 6 & $54.5 \%$ \\
\hline total & 11 & $100 \%$ \\
\hline
\end{tabular}

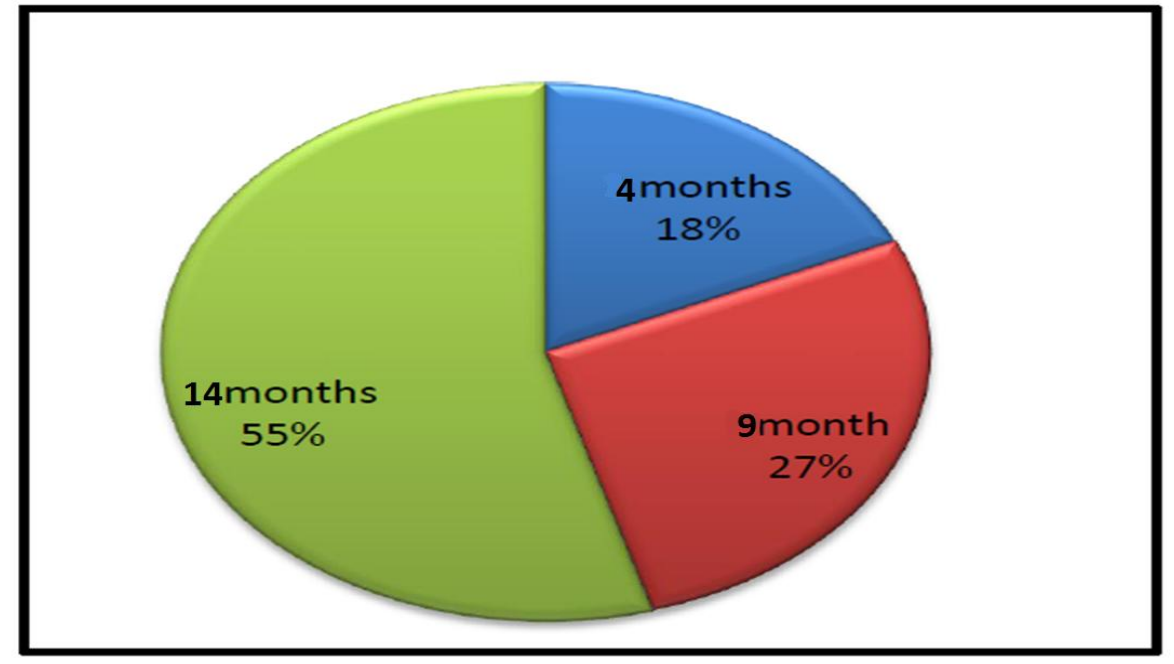

Fig. (4-C)effective of therapy in /month

\section{Side effect ofEpirubicin:-}

Epirubicin $\mathrm{HCl}$ depends in its nanoparticles form to targeting the cancerous cells so it'snot effecting on normal cells; that's why the side effects present by $18.2 \%$ as a serious whilea $81.8 \%$ is common side effects. 
Table 5-C:-Side effect of Epirubicin.

\begin{tabular}{|l|l|l|}
\hline Sideeffect & Number ofpatients & percent \\
\hline common & 9 & 81.8 \\
\hline Serious & 2 & 18.2 \\
\hline Total & 11 & 100 \\
\hline
\end{tabular}

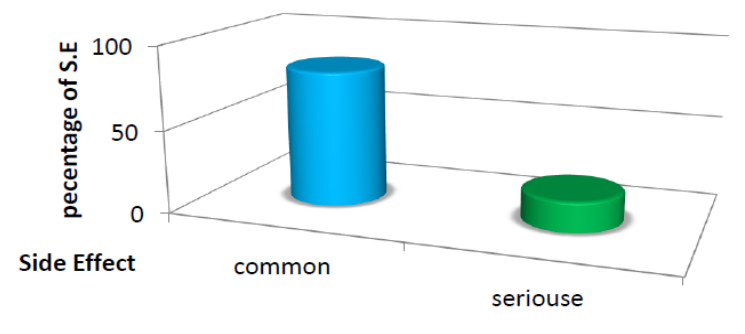

Fig. (5-C)side effect of Epirubicin

Generally chemotherapy targets cell whether normal or cancerous cells; which leads toharm thehealthycellswhichhaveahighrateofgrowthandmultiplicationincludecellsofthe bone marrow. However; the reducing of the serious side effect and duration and thehighly effectivenessofthedrugcanberelatedtoitsnonstructural.Usingmultiwallcarbon nanotubes (MWCNTs) in Epirubicin drug which depend on adsorption ionization methodas antineoplasticagenthelpittobeoneofthemostavailabledrugsintreatingbreastcancer efficientlyandeffectively.Itallowsthemedicationtotransportandtargetthedrugtobe effective Nano-carriers for antitumor therapies.

Epirubicinhasafavorablesafetyprofileandlesssideeffectaftershortdurationofthetreatment.Severalstudiesweredonetoide ntifytheexpandingroleofEpirubicininthetreatmentofbreastcancer .Thesestudieswere matchedwithourstudyinthefollowingpoint:first;Epirubicinhasadvancementinbreastcancertreatment.Afterstudying its effect across a range of subgroups of women with breast cancer includingpremenopausal andpostmenopausalwomen,womenwithaxillarylymphnode-positiveand -negativetumors, and women with either hormone receptor-positive or -negative tumors ofEpirubicin have beenobserved .

As previously reported itisbeingequallyeffectiveandbettertolerated than Doxorubicin in women with metastatic breast cancer and has generally improvedrelapse-free and overall survival compared with standard adjuvant therapies, includingCMF.

Trials of Epirubicin-based regimens in the adjuvant setting are ongoing, andcombinations with newer cytotoxic agents such as the Taxanes, Trastuzumab, and Bisphosphonates arealso being explored in an effort to continue to improve outcomes for patients with breastcancer ${ }^{(42)}$.

Epirubicinalsohaspotentialadvantageinincreasingrateon breast- conservingsurgeryespeciallyincombinationwith Paclitaxel.Theyenabledlumpectomy ina substantialproportion of women who were previously deemed to not be suitable candidates forbreast- conserving surgery ${ }^{(43)}$.

Epirubicin is favorable in the case of the risk of developing congestive heart failure islow . ${ }^{(44)}$

EpirubicinisactiveinmetastaticbreastcancerpatientswhohavepreviouslyreceivedAnthracyclines treatment in the adjuvant setting ${ }^{(45)}$, in advanced breast cancer ${ }^{(46)}$ andhas marker efficiency of Epirubicin in primary breast cancer therapy ${ }^{(47)}$ 
It improves disease-free and overall survival in node-positive breast cancer patients ${ }^{(4)}$ and itis extensively and rapidly metabolized by the liver and also metabolized by other organsand cells, including red blood cells. Epirubicin and its major metabolites are eliminatedthrough biliaryexcretionand,toalesserextent,byurinaryexcretion. Theresultsindicatedthereduced its accumulation in the body (49) which lead to reducing the serious sideeffect.

\section{The study end point:-}

Primary endpoint:-

Theeffectivenessofthedruginthetherapywasmore thanotherchemotherapy.Thedrug rates were significantly higher with lowduration.

\section{Secondary endpoint:-}

$>$ Reducing the most common side effect occurs with all otherchemotherapies.

$>$ Frequencies of the patient hospital income were decreased because of fast progressionin patient health in lessduration.

$>$ Effective of the therapy was highly observed with patients treated with Epirubicin HCldrug

\section{Conclusion:-}

The present study aimed to assess the prevalence of breast cancer in Taif city, the riskfactors cause the disease and the effectiveness of Epirubicin $\mathrm{HCl}$ drug in the treatment as anexample ofnanosystemsdrugbyscreening300women.Fromallthepreviousresultweconcluded that:

$>$ Morethan $10 \%$ ofthepatientshavebreastcancerinperiodabout15monthsindicatingthe highest probability of breast cancer diseases. Breast cancer considered one of themost important causes of death inwomen.

$>$ Risk of breast cancer disease increased by aging; Since the samples of the study wastaken forpatientsin21agesandabove70years,andbycomparingbetweenpatientsintheirage; we found that the risk of breast cancer increased by aging $40.6 \%$ as present in the studyand highly distributed at the ages between 41 to 50 yearsold.

$>$ The personal history of breast cancer increased the risk to develop a new lesionsor recurrence to the first one, we record in this study a $46.9 \%$ patient has recurrencedisease

$>$ Breastcanceristhemostprevalentamongmarriedwomen;wefoundinourdistributed questionnaire the prevalence of breast cancer disease in married woman $(68.8 \%)$.

$>$ The lack of movement is one of the contributing factors and important to developbreast cancer; therefore housewives developed the highest risk of breast cancer $43.7 \%$, and thisrisk decreased if she takes a walk at least for one hour in outdoors like student or employedwho show the least distributed by 18.7 and $37.5 \%$ respectively.

$>$ Increasednumberofbirthswillreducetheriskofbreastcancer;especiallyamongwomen have 1 to 5 times of pregnancy and breastfeeding regularity $(37.5 \%)$.

$>$ Ifthereisafamilymemberhavingbreastcancerthiswillincreaseriskofit;especiallyif he is a very close family member like a mother orsister.

$>$ A longer lifetime exposure to the hormones estrogen and progesterone as ahormonal supplementstherapyincreasestheriskincreasesofbreastcancer.Inthisstudythatresults appear in patients how started menstruating before age 12 by and those howcontinued through after 50 years old or who was using supplement hormonaltherapy.

$>$ Environmentalchemicalcompoundsfoundaroundusincertaincosmetics,personalcareproducts and pesticides has low effect in increasing the risk of breastcancer.

$>$ High-fat diets can lead to being overweight or obese, which is a breast cancer riskfactor

$>$ the patients who exposed to radiation because nature of their work enhanced risk ofgetting breast cancer, they are presented in this study by6.25\%.

$>$ Cigarette smoking cause many cancer types one of it causing breast cancer insmoked patients or exposed to smoke, a $3.13 \%$ from patients in this study have breast cancer dueto smoking even though the lowpercent.

$>$ Thehighawarenessofbreastcancerandhowtodiscoverthedisease,improvetheearly detectionofthe disease andenhancerecoverychances.Inthisstudy46.9\% ofpatients discover the disease by self-examination.

$>$ Highly awareness from doctors of using targeted drug in breast cancer therapy isvery effectiveinmanagingthedisease.Inourstudywefoundthata50\%patientsusetargeted drug in their therapy. 
> Epirubicinisaspecialtypeofchemotherapy;duetoitsdependenceonnanoparticlesinits composition so it's preferred by doctors and patients in its use. This what we demonstratedin this study ; the percentage of patients who are using Epirubicin in their therapy is $43.75 \%$.

$>$ The effectiveness ofEpirubicinbeingbetween3-9months.As54.5\%patientshavethe therapeutic effect of the drug in 9months.

$>$ Epirubicinasatargetedcancertherapyhaslesstoxiceffectthantraditionalchemotherapy drugsbecauseit'stargetingoncancercellsmorethannormalcells.However,targeted cancertherapiescanhavesubstantialsideeffects,butbecauseit'scontainingnanoparticles formtotargetingthecancerouscellswefoundthat $81.8 \%$ patientshaveacommonside effects, while $18.2 \%$ was serious sideeffect.

$>$ EpirubicinisanAnthracyclinesdrugusingNanoparticleinthetherapywhichrepresents advancementinbreastcancertreatment.Inadditionitisbeingequallyeffectiveandbetter toleratedthanotherchemotherapy,duetoitsdependsinitsnanoparticlesformtotargeting the cancerous cells. This explains why it has the highest efficacy and the lowest sideeffects than other chemotherapyagents.

\section{Recommendation:-}

$>$ Spread awareness about breast cancer detection, and how it's important to discoverthe disease and increase effectiveness of therapy if the disease detectedearly.

$>$ Work on the preparation of educational programs by radio, television, social media andother media on the risk factors that cause breast cancer so that people can prevent this diseaseearly

$>$ Encourage mothers to continue breastfeeding their children even after providingadditional food because breastfeeding reduces the incidence of breastcancer.

$>$ Theroleofhealthandmediaorganizationsaroundtheinitialactionsofinfectedwomenand about how note and examine any abnormal swelling through health education for thefamily.

$>$ Encourage doing exercises or at least a walk in outdoors for one hour daily ,because exercises and fresh air reduces risk of getting breastcancer

$>$ Continuous checkup and self-examination for women having high risk to get breastcancer,e.g. family or personal history of breast cancer.

$>$ Stay away from taking hormonal medications and contraception without consultingyour doctors.

$>$ Checkup the environmental chemical and make sure it's not carcinogenic factorsespecially in workarea.

$>$ Balancing foods and diet intake, to regulate the exercise and reducing the chances ingetting breastcancer

$>$ Protect people who work in the fields of radiation by:

$>$ Distance: the radiation intensity decreases as we move away from the source, andthismeans we should keep a suitable distance away from the radiationsource.

$>$ Time:commensuratedoseradiationdirectlyproportionaltotheexposuretimesoitmustperformworkintheregionwheret hereisaradiationassoonaspossibleand efficiently.

$>$ Armor:Thearmorisaprotectivebarriersplacedaroundtheradioactivesourceora source of radiation device.

$>$ Increasetheawarenessofdoctors, healthcareprovidersandpatientsabouttheroleof medications that contain nanotechnology in its composition e.g., Epirubicin drug and howit reduces the side effects and increase the effectiveness of thetherapy.

$>$ We should use a suitable simple and safe nanosystem preparation technique, methodof preparationandthepolymeramongthevariouspossiblemethodstoproducenanoparticles with desired size range with targeting effect and depending on thephysicochemical characteristics of adrug.

$>$ Using of Epirubicin in treatment of breast cancer therapy for 3-9 months isrecommended.

\section{Summary:-}

Thisstudyhavebeendonetoassessthe prevalence ofbreastcancerinTaifcityandtherole of Nanotechnology in Epirubicin drug in its therapy we done this study period from 21 Sep.2014 to 25 Dec. 2015 by taking samples from patient presented tothe hospital in 2014 only. By screening 300 women in Taif city presented to the hospitalin 2014then followed up the cases to Dec. 2015 and analysis the results statistically using SPSS to achieve the objectives ofthe research. We found that the patients how have breast cancer is $10,7 \%$ in 32 case. Thehighest percentageofwomenwithbreastcancerisintheagegroup(41-50).Marriedwomenare

moresusceptibletobreastcancerthansingleone(68.8\%).Supremepercentageofwomen with breast cancer in the sample is housewives and the lowest percentage is students. Riskof breast cancer increase by ageing, family history and changing

the hormone

levelsHigh 
awarenessofbreastcancerscreeningallowedto $46.9 \%$ ofpatientexaminethemselvesand helped them to discover the disease. Reducing the pregnancy age, marriage ageand pregnancy numbers ( 1 to 5) and breastfeeding help in reducing the probability ofbreast cancer disease. Nanotechnology have great important. Nanoparticles presented inthe Epirubicin $\mathrm{HCl}$ shows high effectiveness and less side effects in a period between 3-9months due to targeting the cancerouscells.

\section{References:-}

1. Akashi, K. \&Weissman, I. L. in Developmental Biology ofHematopoiesis (Oxford Univ. Press, New York,2001).

2. Peter C. Nowel. Perspectives in Cancer Research Mechanisms ofTumor

3. Progresion. CANCER RESEARCH 46, 203-207, May1986

4. Cancer Incidence Report Saudi Arabia2010

5. International cancer screening network(ICSN)

6. M. Subramaniam, T.E. Hefferan, K. Tau, D. Peus, M. Pittelkow, S. Jalal,B.L. Riggs,P.Roche,T.C.SpelsbergTissue,celltype,andbreastcancerstage-specific expression of a TGF- $\beta$ inducible early transcription factorgene

7. Allred DC. Ductal carcinoma in situ: terminology, classification, andnatural history. J Natl Cancer InstMonogr. 2010.

8. C.W. ELSTON* and I.O. ELLISpathological prognostic factors in breastcancer. I. The value of histological grade in breast cancer: experience froma largestudywithlong-termfollowup.HistopathologyVolume19,Issue5,pages 403-410, November1991

9. K McPherson, C M Steel, and J M Dixon Breast cancer-epidemiology,risk factors, and genetics BMJ. 2000 Sep 9; 321(7261):624-628.

10. American Cancer Society. Detailed Guide: Breast Cancer. 2014. Accessedat http://www.cancer.org/Cancer/BreastCancer/DetailedGuide/indexon November 13,2014

11. World Cancer Research Fund, American Institute for Cancer Research,Food Nutrition,PhysicalActivityandthePreventionofCancer:AGlobalPerspective

12. Margaret L. McNeely, Kristin L. Campbell, Brian H. Rowe, Terry P.Klassen, JohnR.Mackey,KerryS.CourneyaEffectsofexerciseonbreastcancerpatients and survivors: a systematic review and meta-analysis CMAJ July4,2006 vol. 175 no. 1 doi:10.1503/cmaj.051073

13. Akin, S., Can, G., Aydiner, A., Ozdilli, K., and Durna, Z. (2010). Quality oflife, symptomexperienceanddistressoflungcancerpatientsundergoingchemotherapy. Eur. J. Oncol. Nurs. 14, 400409.doi: 10.1016/j.ejon.2010.01.003

14. Jain K.K. Nanotechnology: applications, market and companies, JainPharma

15. Biotech Publications.2005.

16. TorchilinV.P. Targeted pharmaceutical nanocarriers for cancer therapyand imaging. AAPS. 2007;9:128-147.

17. PulickelM.Ajayan,OttoZ.Zhou.NanotubesofferApplicationsofCarbon Nanotubes. Applied Physics Volume 80, 2001, pp391-425

18. NagavarmaB.V.N., HementK.S.Y., AyazA., $\quad$ VasudhaL.S, ShivakumarH.G. Differenttechniquesforpreparationofpolymeric nanoparticles-Areview. Asian J. of Pharm. and Clinical Research. 2012; 5, 13:17-23.

19. Flahaut, E.; Bacsa, Revathi; Peigney, Alain; Laurent, Christophe(2003). "Gram-Scale CCVD Synthesis of Double-Walled CarbonNanotubes".

20. BegS,RizwanM,SheikhAM,HasnainMS,Anwer

K,KohliK:Advancement incarbonnanotubes:basics, biomedicalapplications andtoxicity. JPharmPharmacol, 2011, 63,141-163

21. HouY1,Effectoftetrandrinecombinedwithepirubicinonthegrowthofhuman breast carcinoma multidrug resistance cell line. YakugakuZasshi.2008Apr;128(4):663-6.

22. Brunbilla C, Ross A,BonfonteV, et al: Phase II study of doxorubicinvs epirubicin in advanced breast cancer.CancerTreat Rep 70:261-266,1986.

23. http://www.rxlist.com/ellence-drug.htm

24. IsmoT. Jantunen, VesaV. Kataja, TimoT. Muhonen, TapaniParviainen, Effects of granisetron with doxorubicin or epirubicin on ECGintervalsCancerChemotherapy and Pharmacology March 1996, Volume 37, Issue 5, pp502504

25. G.Lunardi1,Influenceoftrastuzumabonepirubicinpharmacokineticsinmetastatic breast cancer patientsOxfordJournalsMedicine\&HealthAnnalsof OncologyVolume14, Issue 8Pp.1222-1226.

26. Lisa Schulmeister. Extravasation Management. Seminars in OncologyNursing Volume 23, Issue 3, August 2007, 
Pages 184-190

27. http://seer.cancer.gov/statfacts/html/breast.html

28. AhmedinJemal, Elizabeth Ward and Michael J Thun Recent trends inbreast cancer incidence rates by age and tumor characteristics among U.S.women. Breast Cancer Research 2007,9:R28

29. ShahbaziR, HighBodyMassIndexandYoungAgeArenotAssociatedwith Post-Mastectomy Pain Syndrome in Breast Cancer Survivors: ACase-Control Study, Iran J Cancer Prev. 2015Jan-Feb;8(1):29-35.

30. Croft L, Marital status and optimism score among breast cancer survivors, Support Care Cancer. 2014 Nov;22(11):3027-34. doi:10.1007/s00520-014- 2308-y. Epub 2014 Jun8.

31. Stacy Simon, Study Links Walking to Lower Breast Cancer Risk,America

32. cancer society article, October 4, 2013

33. Azim HA , RANK-ligand (RANKL) expression in young breast cancerpatients andduringpregnancy, BreastCancerRes.2015Feb21;17(1):24.doi:10.1186/s13058-015-0538-7.

34. Eur J Cancer Prev, Breast cancer and ages at first marriage and first birth:a new hypothesis , 2014Jan;23(1):537.

35. William D. Dupont, Ph.D., and David L. Page, M.D , Risk Factors forBreast Cancer in Women with Proliferative BreastDisease

36. World Cancer Research Fund/American Institute for Cancer Research. Food, Nutrition,PhysicalActivity,andthePreventionofCancer:AGlobalPerspective. Washington, DC: American Institute for Cancer Research;2007.

37. M.P.Cleary1,M.E.Grossmann 1andA.Ray.EffectofObesityonBreastCancer Development. Veterinary Pathology March 2010 vol. 47 no. 2202-213

38. Smith RA, Saslow D, Sawyer KA, et al. American CancerSociety guidelines for breast cancer screening: update 2003. CA Cancer JClin. May-Jun2003;53(3):141-69

39. Prentice RL1 , Postmenopausal hormone therapy and the risks ofcoronary heartdisease,breastcancer,andstroke,SeminReprodMed.2014Nov;32(6):419-25. doi: 10.1055/s-0034-1384624. Epub 2014 Oct16.

40. Kelsey JL, Gammon MD, John EM. Reproductive factors andbreast cancer. Epidemiol Rev.1993;15(1):36-47.

41. Collaborative Group on Hormonal Factors in Breast Cancer.Menarche, menopause, and breast cancer risk: individual participantmeta-analysis, including 118964 women with breast cancer from 117epidemiological studies. Lancet Oncol. Nov2012;13(11):1141-51.

42. SemiglazovVF, Moiseenko VM, Manikhas AG, et al. Interim results ofa prospectiverandomizedstudyofselfexaminationforearlydetectionofbreast cancer. VoprOnkol.1999;45(3):265-71.

43. Romond EH, Perez EA, Bryant J, et al. Trastuzumab plusadjuvant chemotherapy for operable HER2-positive breast cancer. N Engl JMed. Oct 202005;353(16):1673-84.

44. Chen BJ1, Small molecules targeting c-Myc oncogene: promisinganticancertherapeutics,IntJBiolSci.2014Sep13;10(10):1084-96.doi:10.7150/ijbs.10190. eCollection2014.

45. Annalsofoncology,Acceleratedversusstandardcyclophosphamide,epirubicinand 5fluorouracilorcyclophosphamide,methotrexateand5-fluorouracil: a randomized phase III trial in locally advanced breastcancer

46. E. Baldini, G. Gardin and others,2002

47. (StefanGlück,MD,PhDTheExpandingRoleofEpirubicinintheTreatment of Breast Cancer Cancer Control March/April 2002, Vol. 9,No.2 Supplement)

48. David Sarid, Neoadjuvant Treatment with Paclitaxel and Epirubicinin Invasive Breast Cancer , Clin Drug Investig.2006;26(12):691-701.

49. GennariA,SalvadoriB,DonatiS,etal:Cardiotoxicityofepirubicin/paclitaxel-containing regimens: Role of cardiac risk factors.J ClinOncol 17:3596-3602,1999.

50. Pierfranco Conte, New Combinations With Epirubicin in AdvancedBreast Cancer, Oncology jurnal app , 2427, 2001.

51. R. D. Jones,A pilot study of quinidine and epirubicin in the treatmentof advanced breast cancer, Br $\mathrm{J}$ Cancer. $1990 \mathrm{Jul} ; 62(1): 133-135$.

52. Ann S. Knoop, Retrospective Analysis of Topoisomerase IIaAmplifications andDeletionsAsPredictiveMarkersinPrimaryBreastCancerPatientsRandomly Assigned to Cyclophosphamide, Methotrexate, andFluorouracil or Cyclophosphamide, Epirubicin, and Fluorouracil: Danish BreastCancer Cooperative Group , American Society of ClinicalOncology 

Abbreviations:-
1. BC : Breast cancer
2. CNT : carbon nanotubes
3. DCI : Ductal carcinoma in situ
4. DLT : dose-limiting toxicities
5. DNA : Deoxyribonucleic acid
6. EPI : Epirubicin hydrochloride
7. f-CNTs : functionalized carbon nanotubes.
8. GRAS : generally recognized as safe
9. HIV : human immunodeficiency virus.
10. IV : intravenous
11. LUVs : large unilamellar vesicles
12. MLVs : Multilamellar vesicles
13. MSNs : mesoporous silica nanoparticles
14. MTD : maximum-tolerated dose
15. MWCNTs : multi wall carbon nanotubes.
16. NNI : National Nanotechnology Initiative
17. PCL : polycaprolactone
18. pCR : pathologic complete response
19. PEG : polyethylene glycol
20. PEI-PEG : polyethylenimine-polyethylene glycol
21. PFS : progression-free survival
22. PLA : poly lactic acid.
23. Ppy : polypyrrole
24. RNA : Ribonucleic acid.
25. SLN : Solid lipid nanoparticles
26. SUVs : small unilamellar vesicles
27. SWCNT : single wall carbon nanotubes. 